\title{
Ecosystem Responses of the Subtropical Kaneohe Bay, Hawaii, to Climate Change: A Nitrogen Cycle Modeling Approach
}

\author{
Katsumasa Tanaka $\cdot$ Michael W. Guidry $\cdot$ Nicolas Gruber
}

Received: 28 February 2013/Accepted: 13 September 2013/Published online: 8 October 2013

(C) Springer Science+Business Media Dordrecht 2013

\begin{abstract}
The global coastal zone is characterized by high biological productivity and serves as an important channel through which materials are transferred from land to the open ocean, yet little is known how it will be affected by climate change. Here, we use Kaneohe Bay, Hawaii, a semi-enclosed subtropical embayment partially surrounded by a mountainous watershed and fed by river runoff as an example to explore the potential impact of climate change on the pelagic and benthic cycling of nitrogen. We employ a nine-compartment nitrogen cycle biogeochemical box model and perturb it with a set of four idealized climate scenarios. We find that hydrological changes play a dominant role in determining the ecosystem structure, while temperature changes are more important for the trophic state and stability of the ecosystem. The ecosystem stability against storm events does not significantly change under any scenario. The system remains autotrophic in the future; however, it becomes significantly less autotrophic under drier climate, while it turns slightly more autotrophic under wetter climate. These findings may have implications for other high island watershed and coastal ecosystems in the tropics and subtropics.
\end{abstract}

Electronic supplementary material The online version of this article (doi:10.1007/s10498-013-9209-4) contains supplementary material, which is available to authorized users.

K. Tanaka

Institute for Atmospheric and Climate Science, Swiss Federal Institute of Technology (ETH Zurich), Universitaetstrasse 16, CHN N16.1, 8092 Zurich, Switzerland

K. Tanaka $(\bowtie)$

Institute for Advanced Sustainability Studies e.V. (IASS), Potsdam, Germany

e-mail: katsumasa.tanaka@iass-potsdam.de

M. W. Guidry

Department of Oceanography, University of Hawaii at Manoa, Honolulu, HI, USA

N. Gruber

Institute of Biogeochemistry and Pollutant Dynamics, Swiss Federal Institute of Technology

(ETH Zurich), Zurich, Switzerland 
Keywords Ecosystem modeling - Estuarine dynamics $\cdot$ Nitrogen cycle $\cdot$ Nutrient limitation · Climate change · Hawaii · Kaneohe Bay

\section{Introduction}

The coastal ocean is a key domain for the global biogeochemical cycles of the elements and plays a major role in regulating nutrient transport from the land to the open ocean (Smith and Hollibaugh 1993; Ver et al. 1994; Mackenzie et al. 1998; Tanaka and Mackenzie 2005; Mackenzie and Lerman 2006; Mackenzie et al. 2011; Regnier et al. 2013). The coastal zone receives nutrient input fluxes [e.g., nitrogen $(\mathrm{N})$ and phosphorus $(\mathrm{P})$ ] from river, dust, groundwater, land-derived inputs, and upwelling inputs from the open ocean. Although the coastal ocean accounts for only $10 \%$ of the global ocean surface area, it is responsible for $25 \%$ of global ocean primary production and $80 \%$ of global organic carbon (C) burial (Smith and Hollibaugh 1993). Tropical and subtropical island coastal regimes support critical ecosystems (e.g., mangroves, coral reefs, and near-shore fisheries) and provide numerous economic, cultural, and esthetic benefits for coastal populations (Guidry et al. 2012). The physical, chemical, and biological properties of these coastal ecosystems are controlled by a variety of often coupled and interactive factors [e.g., watershed land-use patterns; river runoff; dissolved and particulate loads of runoff; exchange with the open ocean through both offshore and onshore advection and diffusion and upwelling; tidal mixing; seasonal and longer-term evaporation and precipitation variability (Summerhayes 1995)]. These subtropical and tropical coastal zones are therefore highly susceptible to cultural eutrophication and climate change-related processes such as ocean warming, ocean acidification, deoxygenation, and extreme events involving heavy precipitations [e.g., (Rabouille et al. 2001; Doney 2010; Gruber 2011; Rees 2012; Seneviratne et al. 2012)]. The coastal zone hosts complex interactions and feedbacks in the coupled pelagic and benthic system, and it is worthwhile to explore how coastal ecosystems might be shaped by ongoing and future environmental and climate changes by means of modeling.

This study takes the Kaneohe Bay ecosystem as an example. Kaneohe Bay is a subtropical shallow embayment (often referred to as an estuary) located on the eastern windward side of the island of Oahu, Hawaii [Fig. 1 of (Tanaka and Mackenzie 2005)]. The bay has an average depth of 8 meters $(\mathrm{m})$, and its dimensions are approximately $13 \mathrm{~km}$ $(\mathrm{km})$ long and $4 \mathrm{~km}$ wide (Smith et al. 1981). The average residence time of bay water is between 5 and 8 days and up to 30 days in the south basin [e.g., (Smith et al. 1981; Lowe et al. 2009)]. A large barrier reef extends across the central portion of the distal bay, and numerous patch reefs are found within the bay. A northwest-southeast trending basin with a maximum depth of $12 \mathrm{~m}$ and floored by fine-grained carbonate sands and mud is located landward of the barrier reef with terrigenous sediments along the coastal margin of the bay. Annual precipitation rates in the Kaneohe Bay watershed vary from approximately 100 to $350 \mathrm{~cm}$ year $^{-1}$ and have a long-term yearly mean of $250 \mathrm{~cm}$ (Giambelluca et al. 2008). Approximately three-fourths of total runoff to Kaneohe Bay enters the southern basin via Kaneohe Stream. The mean discharge rate for Kaneohe Stream is $0.20 \mathrm{~m}^{3} \mathrm{~s}^{-1}$ (Ringuet and Mackenzie 2005; Hoover and Mackenzie 2009; Drupp et al. 2011). Tidal range is not large ( $<2 \mathrm{~m}$ ), and the tide is diurnal (Ringuet and Mackenzie 2005; Ostrander et al. 2008). General bay circulation is driven by the diurnal tidal cycle, incoming wave, and wind 

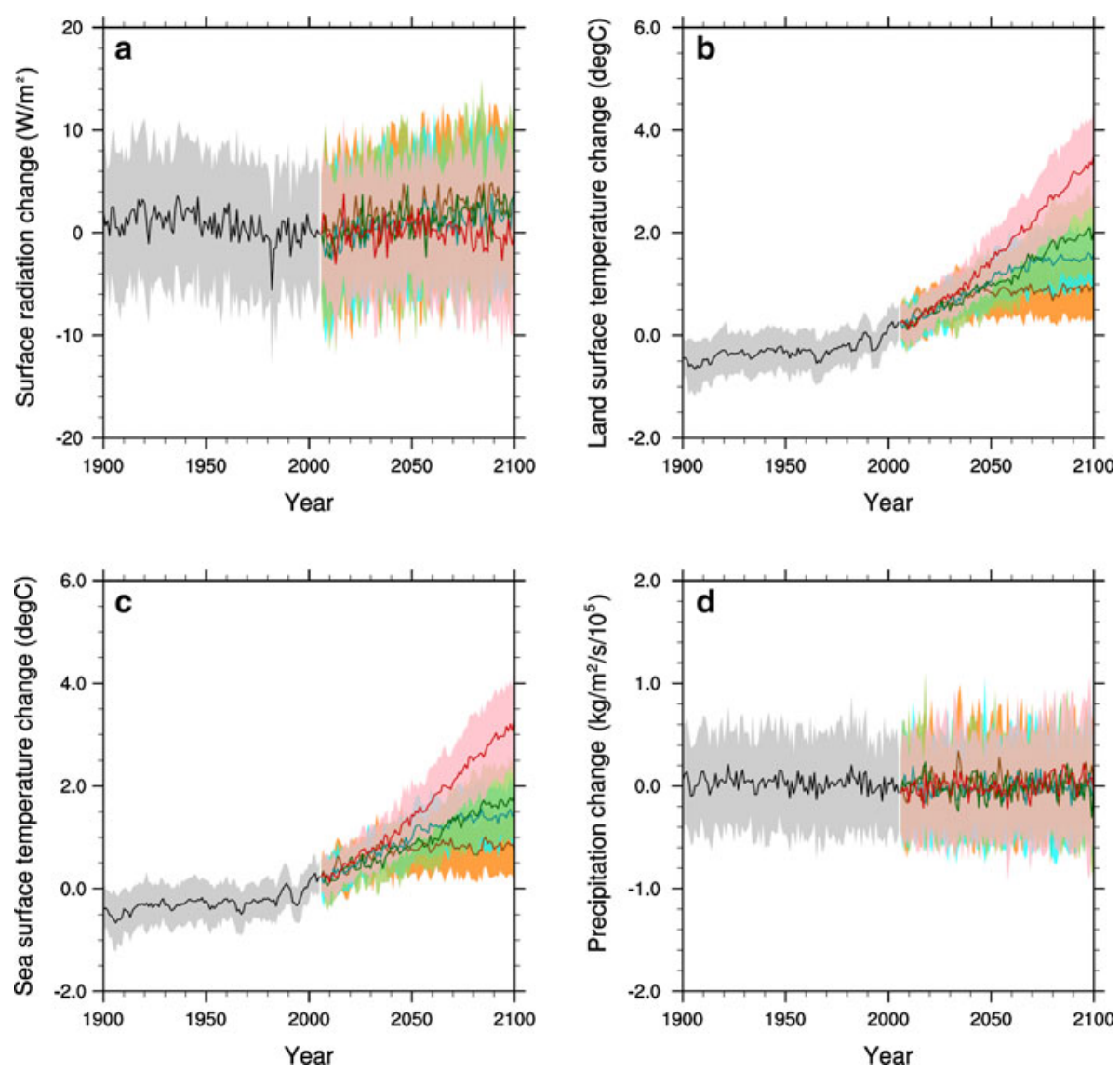

Fig. 1 All-sky surface radiation (a), LST (b), SST (c), and precipitation changes (d) of the CMIP5 model grid cell containing Kaneohe Bay. The location of the selected model grid cell is $21.25 \mathrm{~N}$ and $156.25 \mathrm{~W}$ (cf. the actual bay location is $21.27 \mathrm{~N}$ and $157.48 \mathrm{~W}$ ) - note that the Hawaiian Islands are not resolved in any models used for the CMIP5 project. Solid lines are mean projections; shaded area show corresponding $1 \sigma$ ranges. Red, blue, green, and orange are the color designations used for projections based on RCP2.6, 4.5, 6.0 , and 8.5 , respectively. See text for further details

forcing, although the southern basin exchange is effectively isolated from wave and ocean swell energy and is primarily driven by trade wind (Ostrander et al. 2008; Lowe et al. 2009). The relatively sluggish circulation in the southern basin allows the signature of anthropogenic pollution to be exhibited more clearly than in other parts of the bay.

The Kaneohe Bay has a unique history, making the bay's ecosystem an ideal site for biogeochemical studies. In the surrounding mountainous watershed area, a human population of approximately 73,000 resides within the two towns of Kaneohe and Kailua (US-Census-Bureau 2012). During the post-contact period (i.e., post-Western contact with the native Hawaiians in the year 1778 by Captain Cook), human settlement of the Kaneohe Bay watershed became significant in the 1950s. Settlement and development led to significant sewage discharge of inorganic $\mathrm{N}$ and $\mathrm{P}$ and organic $\mathrm{C}$ to the southern bay water. The bay was heavily polluted until the sewage outfalls were diverted out of the bay in 1978. The water quality and trophic state of the ecosystem before and after the sewage 


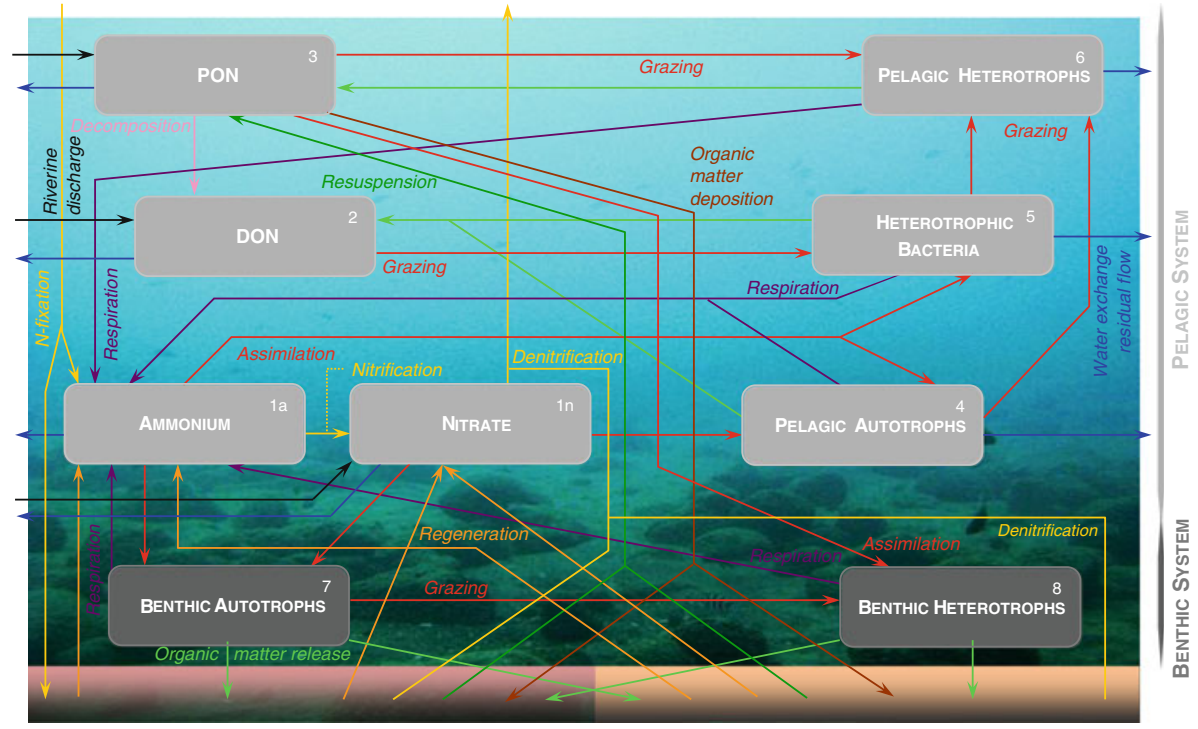

REEF Sediments

LAGOON SEDIMENTS
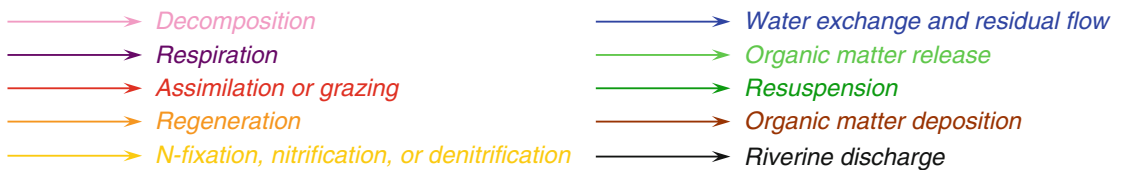

Fig. 2 Conceptual diagram of KECOM. The numbers and letters in the reservoir boxes denote the reservoir designations used for model equations. Descriptions of the fluxes are provided along the arrows in correspondingly designated colors

diversion were extensively studied [e.g., (Smith et al. 1981; Jokiel et al. 1993)], and monitoring and observational studies continue today [e.g., (Laws and Allen 1996; Ringuet and Mackenzie 2005; Scheinberg et al. 2005; Tanaka and Mackenzie 2005; Cox et al. 2006; Fagan and Mackenzie 2007; Hoover and Mackenzie 2009; Drupp et al. 2011; Shamberger et al. 2011; Massaro et al. 2012)].

Our study focuses on the $\mathrm{N}$ cycle. It has been shown that the bay ecosystem is currently limited by $\mathrm{N}$ under baseline conditions (Smith et al. 1981; Laws and Allen 1996), while a P limitation emerges under extreme perturbations such as storm attacks (Ringuet and Mackenzie 2005; De Carlo et al. 2007). Thus, the N cycle plays a key role in determining the trophic state of the ecosystem. $\mathrm{N}$ also affects the stability of the ecosystem (i.e., the time for the ecosystem to recover from a perturbation). Note, however, that addressing the $\mathrm{N}$ cycle alone misses other potentially important processes such as changes in the coral reef community due to rising temperatures and ocean acidification (Buddemeier et al. 2004; Carpenter et al. 2008; Drupp et al. 2011), which may affect and be affected by processes involving the N cycle (Smith et al. 1981; Jokiel et al. 1993).

Various climatic and environmental changes in Hawaii have already been reported. The direct solar irradiance measured at Mauna Loa, Hawaii, for the last five decades has exhibited interannual and decadal variations reflecting background stratospheric aerosol loads, punctuated in a few instances by abrupt drops caused by volcanic eruptions 
(Solomon et al. 2011). Other factors such as local cloud cover and air pollution influence more strongly the surface radiation that actually reaches the bay. Since 1975, land surface temperature (LST) measured at stations located in the Hawaiian Islands have been increasing at a mean rate of $0.163{ }^{\circ} \mathrm{C}$ decade $^{-1}$, a rate close to the global-mean estimate despite Hawaii's subtropical location (Giambelluca et al. 2008). Since the late 1970s, the diurnal temperature range observed in Hawaii has been decreasing (Giambelluca et al. 2008), which is possibly an indication of the enhancing anthropogenic greenhouse effect (Stone and Weaver 2002; Braganza et al. 2004; Meehl et al. 2004). Sea surface temperature (SST) measured at a station at Koko Head, Oahu, has been rising at a rate of $0.15{ }^{\circ} \mathrm{C}$ decade $^{-1}$ since the 1950s (Jokiel and Brown 2004). The inshore water temperature of the bay may have been influenced by the recent elevation of open ocean SST as well as by other local conditions such as tides, bay currents, and fluctuations in solar radiation and wind field. The SST measured in the inner part of the barrier reef in the central portion of Kaneohe Bay [Coral Reef Instrumented Monitoring Platform (CRIMP2) buoy] for the past several years does not show any annualized temperature change (Eric De Carlo, personal communication, November 12, 2012). Observed changes in precipitation patterns since the 1980s show more frequent light precipitation events but less frequent moderate and heavy precipitation events (Chu et al. 2010). The dominant direction of the trade winds measured at land and buoy stations has been shifting from northeast to east during the past 30 years (Garza et al. 2012).

This study tackles the following question: how might the southern Kaneohe Bay ecosystem be affected by the future climate change? We employ an $\mathrm{N}$ cycle model describing pelagic and benthic ecosystem processes in the southern Kaneohe Bay watershed (Tanaka 2002; Tanaka and Mackenzie 2005) and probe the sensitivity of the bay's N cycling to a range of solar irradiance, water temperatures, residence times, runoff rates, and intensities of a single storm-driven precipitation event. Our study then investigates annualized ecosystem responses under selected states of future climate that may impact the bay at the end of the twenty-first century. Furthermore, we look into how future climate change might influence the ecosystem stability.

\section{Model Description and Experimental Setup}

\subsection{Model Description}

We employ the Kaneohe Bay ECOsystem Model (KECOM) (Tanaka 2002; Tanaka and Mackenzie 2005; Fig. 2) . KECOM is a nine-compartment box model describing major $\mathrm{N}$ cycle processes occurring in the pelagic and benthic components of the southern Kaneohe Bay ecosystem. KECOM is one of the few dynamic modeling approaches to elucidate the ecosystem dynamics in Kaneohe Bay (Caperon 1975; Tanaka and Mackenzie 2005). The model setup (i.e., governing equations, parameter values, and initial reservoir sizes) is based on previous studies (Tanaka 2002; Tanaka and Mackenzie 2005). Below, we highlight the model structure directly relevant to this study. ${ }^{1}$

The model contains nine reservoirs in the pelagic and benthic systems of the southern Kaneohe Bay: ammonium, nitrate, dissolved organic nitrogen (DON), particulate organic

\footnotetext{
${ }^{1}$ KECOM written using the software package of STELLA ${ }^{\circledR}$ version 9.1.4. The time step of model runs is $2^{-13}$ years $(\approx 1.1 \mathrm{~h})$. This time step is chosen to ensure numerical stability in the simulations of the fast $\mathrm{N}$ turnover in the modeled food web. The fourth Runge-Kutta method is used for numerical integrations.
} 
nitrogen (PON), pelagic autotrophs, pelagic heterotrophic bacteria, pelagic heterotrophs, benthic autotrophs, and benthic heterotrophs. The reservoirs are connected via fluxes representing $\mathrm{N}$ cycle processes such as decomposition of PON to DON, respiration, assimilation, grazing, remineralization, $\mathrm{N}$-fixation, nitrification, denitrification, water exchange, riverine discharge, excretion, and deposition and resuspension of PON (nonexhaustive). The sediments are treated outside of the model boundary. However, fluxes to and from the sediments (e.g., PON deposition and resuspension, remineralization, N-fixation, and denitrification) are provided in the model and play important roles in regulating nutrient dynamics. The bathymetry of the southern bay is assumed to fall into the following two types: the shallower reef sediments and the more extensive and deeper lagoon sediments. All the benthic biota is assumed to live on the reef environment because the reef biota is far more important than the lagoon biota with respect to the nutrient cycling of the bay.

Dynamic equations representing fluxes are given in various forms. Most of the fluxes are described by first-order kinetic equations (i.e., the flux magnitude assumed proportional to the size of the reservoir where the flux originates) or zero-order equations (i.e., the flux magnitude assumed to be constant over time). Allochthonous fluxes such as evaporation, precipitation, residual flow, stream input, and water exchange are zero-order equations. The rate of the residual flow is adjusted to maintain the hydrological balance of the southern bay when, for example, a storm event is added through an elevation of the river flow. The river flow in the model contains nitrate, DON, and PON at the concentration of 50,25 , and $25 \mu \mathrm{mol} \mathrm{N} / \mathrm{l}$, respectively [Table 1 of (Tanaka and Mackenzie 2005)]. The ammonia concentration in the river runoff is assumed to be zero; ammonia is detected in the actual river flow, and its level generally depends on the flow rate (Hoover and Mackenzie 2009; Wong 2013), but the dissolved inorganic nitrogen (DIN) in the streams is in most cases dominated by nitrate. It is assumed that there is no sewage input into the bay in the model although minor discharge of non-point-source sewage remains. Equations for the fluxes describing biological metabolism take more complicated forms as discussed below.

Biological metabolism of the heterotroph reservoirs is regulated by two factors: nutrient/food availability and water temperature. Autotrophic reservoirs have an additional regulating factor: light availability. Functional forms representing these three regulating factors are summarized in Table 1.

- Light regulation: Pelagic autotrophs are assumed to be homogeneously distributed vertically as well as horizontally in the bay water having an equal depth of $9.51 \mathrm{~m}$, while benthic autotrophs are assumed to be situated at an equal depth of $0.65 \mathrm{~m}$ on the reef sediments (Smith et al. 1981). Due to the vertical distribution of pelagic autotrophs, the equation describing the light limitation for pelagic autotrophs is more complex than that for benthic autotrophs. The inhibition of photosynthesis under strong irradiance during midday is taken into account.

- Temperature regulation: Autotrophs and heterotrophic bacteria (Q10 values of 1.9) are assumed to be less sensitive to the water temperature change than heterotrophs $(\mathrm{Q} 10$ values of 2.7) (White et al. 1991; Laws et al. 2000).

- Nutrient/food regulation: The nutrient/food limitation for all the biotic reservoirs is modeled using a third-power Michaelis-Menten kinetic function because the standard Michaelis-Menten kinetic function (i.e., to the power of one) does not provide a sufficient stability for our modeled ecosystem to dampen perturbations [Figs. 3. 18 and 3.19 of (Tanaka 2002); (Tanaka and Mackenzie 2005)]. This choice, while somewhat arbitrary, is well within the range of parameterizations that have been discussed and 
Table 1 Factors regulating biological metabolism described in KECOM

\begin{tabular}{|c|c|c|c|}
\hline \multirow[t]{2}{*}{ Biotic reservoir } & \multicolumn{3}{|l|}{ Regulating factors } \\
\hline & Light & Temperature & Nutrient/food \\
\hline Pelagic autotrophs (4) & $\begin{array}{c}\frac{c_{\mathrm{pi}} c_{\mathrm{pp}} e^{1}}{B_{4}} \times\left\{e^{-\frac{I_{0}}{I_{\mathrm{opt}}} \exp \left(-B_{4}\right)}-e^{-\frac{I_{0}}{I_{\mathrm{opt}}}}\right\} \text { where } \\
B_{4}=\left\{c_{\mathrm{W}}+c_{\mathrm{ds}}\left(\left[N_{3}\right]+\left[N_{4}\right]\right)\right\} z_{\text {Bay }}\end{array}$ & $e^{c_{\mathrm{Q} 10 \mathrm{~A}}\left(T_{\mathrm{Bay}}-25\right)}$ & $\frac{\left(N_{\mathrm{la}}+N_{\mathrm{ln}}\right)^{c} \mathrm{MM}}{\left(N_{\mathrm{la}}+N_{\mathrm{ln}}\right)^{c^{\mathrm{MM}}+\left(P_{4}\right)^{c} \mathrm{MM}}}$ \\
\hline Heterotrophic bacteria (5) & N/A & $e^{c_{\mathrm{Q} 10 \mathrm{~A}}\left(T_{\mathrm{Bay}}-25\right)}$ & $\frac{\left(N_{\mathrm{la}}+N_{2}\right)^{c} \mathrm{MM}}{\left(N_{\mathrm{la}}+N_{2}\right)^{c \mathrm{MM}}+\left(P_{5}\right)^{\mathrm{c} \mathrm{MM}}}$ \\
\hline Pelagic heterotrophs (6) & N/A & $e^{c_{\mathrm{Q} 10 \mathrm{H}}\left(T_{\mathrm{Bay}}-25\right)}$ & $\frac{\left(N_{3}+N_{4}+N_{5}\right)^{c \mathrm{MM}}}{\left(N_{3}+N_{4}+N_{5}\right)^{c} \mathrm{MM}+\left(P_{6}\right)^{c \mathrm{MM}}}$ \\
\hline Benthic autotrophs (7) & $\begin{array}{l}\frac{I_{\mathrm{R}}}{I_{\mathrm{opt}}} e^{1-\left(I_{\mathrm{R}} / I_{\mathrm{opt}}\right)} \text { where } \\
\quad I_{\mathrm{R}}=I_{0} e^{-\left\{c_{\mathrm{w}}+c_{\mathrm{ds}}\left(\left[N_{3}\right]+\left[N_{4}\right]\right)\right\} z_{\mathrm{R}}}\end{array}$ & $e^{c_{\mathrm{Q} 10 \mathrm{~A}}\left(T_{\mathrm{Bay}}-25\right)}$ & $\frac{\left(N_{\mathrm{la}}+N_{\mathrm{ln}}\right)^{c} \mathrm{MM}}{\left(N_{\mathrm{la}}+N_{\mathrm{ln}}\right)^{\mathrm{CMM}}+\left(P_{7}\right)^{c^{\mathrm{M} M}}}$ \\
\hline Benthic heterotrophs (8) & N/A & $e^{c_{\mathrm{Q} 10 \mathrm{H}}\left(T_{\mathrm{Bay}}-25\right)}$ & $\frac{\left(N_{3}+N_{7}\right)^{c^{\mathrm{MM}}}}{\left(N_{3}+N_{7}\right)^{c^{\mathrm{MM}}}+\left(P_{8}\right)^{\mathrm{c}^{\mathrm{MM}}}}$ \\
\hline
\end{tabular}

The numbers within the parentheses after the reservoir names correspond to those given in Fig. 3 and reservoir designations used for model equations. $c_{\mathrm{pp}}, c_{\mathrm{pi}}, c_{\mathrm{ds}}$, and $c_{\mathrm{w}}$ denote an average photoperiod as a fraction of a day, a correction term for the effect of surface photo-inhibition during midday, an attenuation coefficient of phytoplankton self-shading and detritus, and an attenuation coefficient of water and substances other than chlorophyll and PON, respectively. $I_{0}$ and $I_{\text {opt }}$ indicate a daily averaged irradiance level during photoperiod just below the sea surface and an optimal irradiance level to yield maximum primary production, respectively. $z_{\text {Bay }}$ and $z_{\mathrm{R}}$ are the mean depths of southern Kaneohe Bay and reef sediments, respectively. $N_{i}$ is the $\mathrm{N}$ mass of reservoir $i ;\left[N_{i}\right]$ is the $\mathrm{N}$ concentration of reservoir $i$. $P_{j}$ is the MichaelisMenten kinetic constant used to describe the metabolism of reservoir $j . c_{\mathrm{MM}}$ is the power applied to the Michaelis-Menten kinetic functions used in this model. $T_{\mathrm{Bay}}$ is the average temperature of Kaneohe Bay water. $c_{\mathrm{Q} 10 \mathrm{~A}}$ and $c_{\mathrm{Q} 10 \mathrm{H}}$ are coefficients for temperature regulations of autotrophs (including heterotrophic bacteria) and heterotrophs, respectively. These coefficients take values of 0.0633 and 0.1 , respectively. For further details of the coefficients and parameters appearing in this table, see Table 4 of (Tanaka and Mackenzie 2005)

adopted for the study of nutrient or food limitation of organisms [e.g., (Dugdale 1967; Pace et al. 1984; Fennel 1995; Laws et al. 2000; Gross et al. 2004)].

Note that changes in surface radiation and water temperature do not influence the magnitudes of fluxes other than biotic fluxes discussed above.

Denitrification and N-fixation fluxes (see (Galloway et al. 2004; Gruber 2008) for overviews) have a large influence on the $\mathrm{N}$ budget of the bay. Certain species of heterotrophic bacteria utilize denitrification processes in the anoxic environment and respire large amounts of organic matter by using nitrate as electron acceptors. Denitrification is thought to be quantitatively more important in the sediments than in the water column. We approximate the rate of denitrification occurring in the sediments as well as in the water column to be proportional to the size of the nitrate reservoir. $\mathrm{N}$-fixation is undertaken primarily by autotrophs but also by bacteria in environments where fixed $\mathrm{N}$ is unavailable. The N-fixation flux (i.e., an influx to the ammonium reservoir) is assumed to be proportional to the total size of the pelagic phytoplankton and heterotrophic reservoirs.

The initial reservoir masses are estimated based on the measurements collected through the Coastal Intensive Site Network (CISNet) observational campaign (Tanaka and Mackenzie 2005; Cox et al. 2006). KECOM has been tuned based on observations (Hoover 2002) and produces a steady state representing the present annual-mean baseline condition of the bay ecosystem. The initial reservoir sizes are summarized in Table 1 of (Tanaka and 
Mackenzie 2005), and the initial magnitudes of fluxes are shown in Fig. 3.2 of (Tanaka 2002). Furthermore, KECOM has been applied to investigate the ecosystem response to a storm perturbation (Tanaka and Mackenzie 2005), and the directions of the changes in the state variables agree reasonably well with observational data obtained for a storm event during May 6, 2002-May 15, 2002 (Ringuet and Mackenzie 2005).

\subsection{Future Climate Scenarios}

We construct future climate scenarios by synthesizing relevant literature and output of largescale state-of-the-art Earth System Models (ESMs). The ESM output we use is obtained from the Coupled Model Intercomparison Project Phase 5 (CMIP5) (Taylor et al. 2011). The ESM runs are driven by the Representative Concentration Pathways (RCP) (Moss et al. 2010), a set of four emissions scenarios of greenhouse gases and relevant components reflecting possible socioeconomic development pathways until the year 2300 that lead to stabilizations of the total radiative forcing at $2.6,4.5,6.0$, and $8.5 \mathrm{~W} / \mathrm{m}^{2}$, respectively. All the four scenarios share a common historical emission trajectory from the year 1850 to 2005. Results for the model grid cell containing Kaneohe Bay are shown in Fig. 1. ${ }^{2}$ Different colors represent socioeconomic uncertainties, while shaded areas show physical climate and biogeochemical uncertainties. It should be pointed out that projections of the future climate pertinent to the bay are suffered from the inability of ESMs to spatially resolve how local orographic features influence local climate processes. ${ }^{3}$ The number of regional modeling and statistical downscaling studies that circumvent this problem is limited.

With these difficulties in mind, we design four types of annual-mean climate scenarios of the bay at the end of the twenty-first century (Table 2). Projections of the ESMs show a range of warming toward the end of this century. Climate scenarios I and I' address a moderate warming and scenarios II and II' a more enhanced warming. Future precipitation amounts are projected to decrease in winter but increase in summer (Timm and Diaz 2009), leading us to consider two alternate sets of future hydrology. The first set of scenarios (I and II) envisions a drier climate than that of today, which is likely to result in less cloud cover (i.e., stronger surface radiation) and reduced river runoff. In contrast, the second set of scenarios (I' and II') attempts to mimic conditions of a wetter climate compared to the present day, which may result in a decrease in surface radiation and an increase in river runoff. Thus, in setting up the climate scenarios, we change the following four parameters: solar radiation, water temperature, water exchange, and river runoff. ${ }^{4}$

\footnotetext{
${ }^{2}$ When multiple runs using a same emissions scenario are available from a single model, one run is chosen based on visual inspection (Jan Sedlacek, personal communication, 23 November 2012). Selected runs from each model are simply averaged, although weighting among models is an issue of ongoing debate (Knutti 2010).

3 The current upward trend of the global-mean surface temperature is likely to continue for the next several decades owing to the biogeochemical and physical inertia arising from the long residence time of $\mathrm{CO}_{2}$ in the atmosphere (Archer et al. 2009) as well as the slow heat transfer processes in the ocean (Solomon et al. 2010) even if anthropogenic emissions of greenhouse gases, pollutants, and aerosol precursors are drastically reduced in the near future [(Tanaka and Raddatz 2011); further references therein]. However, while global-mean surface temperatures are projected to increase for the next several decades, how that increase, in turn, influences the regional and local climate pattern germane to Kaneohe Bay is not as well-known.

4 The precipitation and evaporation parameters are kept at their respective reference levels for the present day (Tanaka and Mackenzie 2005). Changes in these parameters within substantial ranges of $\pm 20 \%$ do not result in any significant adjustments in reservoir sizes (results not shown). Water exchange is far more important in controlling the hydrological budget of the bay.
} 
Table 2 Illustrative future climate scenarios of Kaneohe Bay used in our analysis

\begin{tabular}{llllll}
\hline Future climate scenarios & Surface radiation & Water temperature & Water exchange & River runoff \\
\hline I & Drier warmer climate & $10 \% \nearrow$ & $2{ }^{\circ} \mathrm{C} \nearrow$ & $10 \% \searrow$ & $10 \% \searrow$ \\
I' & Wetter warmer climate & $10 \% \searrow$ & $2{ }^{\circ} \mathrm{C} \nearrow$ & $10 \% \searrow$ & $10 \% \nearrow$ \\
II & Drier hotter climate & $10 \% \nearrow$ & $4{ }^{\circ} \mathrm{C} \nearrow$ & $10 \% \searrow$ & $10 \% \searrow$ \\
II' & Wetter hotter climate & $10 \% \searrow$ & $4{ }^{\circ} \mathrm{C} \nearrow$ & $10 \% \searrow$ & $10 \% \nearrow$ \\
\hline
\end{tabular}

" $\nearrow$ " and " $\searrow "$ indicate an increase and a decrease, respectively. In the reference case, the water temperature is $25{ }^{\circ} \mathrm{C}$; the rate of water exchange is $2.2 \times 10^{9}\left(\mathrm{~m}^{3} /\right.$ year); the rate of river runoffs (base rates excluding storm-related discharges) to the southern Kaneohe Bay is $2.78 \times 10^{7}$ ( $\mathrm{m}^{3} /$ year). References are found in Table 4 of (Tanaka and Mackenzie 2005)

- Surface radiation: In the CMIP5 runs (Fig. 1a), mean surface radiation levels do not significantly change till the end of the twenty-first century (only slight increases of up to $1 \%$ ), and the uncertainty ranges remain substantial, irrespective of the underlying emissions scenarios. In our climate scenarios, all-sky surface radiation reaching the bay surface is varied by $10 \%$ positively or negatively on the basis of the uncertainty range in CMIP5 runs, which are their conceivable limits to explore maximum ecosystem changes. The use of the upper and lower limits of the uncertainty ranges partly compensates for the possible underestimates of decadal changes in model-based surface radiation [e.g., (Ohmura 2009; Wild 2009; Skeie et al. 2011)].

- Water temperature: The bay water temperature is assumed to rise by 2 or $4{ }^{\circ} \mathrm{C}$ relative to the present-day temperature based on the year 2100 SST ranges shown by the CMIP5 models (Fig. 1c). SST shows about the same level of warming as that of LST (Fig. 1b). The actual bay temperature is subject to not only the ambient SST but also local factors such as tides, currents, solar radiation, and wind field that are not well resolved by the CMIP5 models. Note that the level of warming in this paper is defined relative to the present-day level, unlike the $2{ }^{\circ} \mathrm{C}$ warming discussed as a climate policy target, which is defined relative to the preindustrial level.

- Water exchange: Mixing in the southern bay is primarily driven by wind (Ostrander et al. 2008; Lowe et al. 2009). The dominant direction of the measured trade winds has been shifting from northeast to east during the past 30 years (Garza et al. 2012), leading to the shortening fetch that results in a reduced mixing of the southern bay. We assume that the mixing efficiency of the bay is reduced by an arbitrary level of $10 \%$ at the end of this century.

- River runoff: The CMIP5 runs do not clearly show the direction of the future change in precipitation, but the range of precipitation becomes slightly larger toward the future in all the four cases. In these model simulations, however, orographic precipitation, a process that is critical to ecosystem dynamics of the Kaneohe Bay, is not spatially resolved. A downscaling study shows a 5-10\% decrease in the wet-season precipitation and a $5 \%$ increase during the dry season due to a change in wind direction during the late twenty-first century (Timm and Diaz 2009). A hydrological modeling study (Safeeq and Fares 2012) showed that future runoff rates of streams in western Oahu have a large uncertainty spanning between negative and positive estimates of runoff, depending on precipitation, watershed vegetation, and temperature. In our scenarios, we consider possibilities of $10 \%$ increase and $10 \%$ decrease in annual-mean river runoff rates. Extreme events followed by heavy precipitation (Norton et al. 2011) are not taken into account in the assumptions of the future base flow rates. 


\subsection{Experimental Setups}

Our experimental setups are designed to investigate how the ecosystem adjusts to the given climate scenarios at the annual-mean level as well as how the ecosystem responds to a storm perturbation under such scenarios. In year 0 , all the runs start with the same initial condition. In sensitivity runs, different climate scenarios are imposed in year 0 . Such initial changes in climate lead to a phase of adjustments for as long as several months. In year 0.8 (after the completions of initial adjustments), all the runs are perturbed by a synthetic storm event for approximately 3 days, during which the rate of river flow is elevated by fivefold. Model runs continue till year 2.0, when storm perturbations decay and the steady state is recovered. Several notes follow:

- Such spinup runs are short but sufficient for our modeling approach. Under each scenario imposed, the ecosystem finds a new equilibrium within a few months. The short equilibration time is due to the absence of long-term sedimentary processes in the model.

- The magnitude and the duration of this storm perturbation are consistent with those used in (Tanaka and Mackenzie 2005). Such a perturbation size is comparable to observed storm-generated changes in river runoff rates to Kaneohe Bay (Hoover 2002; Ringuet and Mackenzie 2005).

- The composition of the river water is assumed to be invariant during the storm perturbation, although in reality, it varies depending on the timing and the magnitude of an actual storm event [(Hoover and Mackenzie 2009); Eric De Carlo, personal communication, December 22, 2012].

- The experimental setups assume that coefficients determining biological metabolism are the same with those estimated for the present ecosystem, which implies that the biological community structure under new climate scenarios are assumed to be invariant. This assumption can be debatable in consideration of the increases in alien algae in benthic systems (Smith et al. 2001, 2002), for example.

Furthermore, we perform a series of sensitivity analyses with respect to each of the following parameters to understand fundamental characteristics of the model ecosystem. ${ }^{5}$ Results are shown in Supplementary Material and discussed in text where necessary.

- Storm perturbation: The rate of river flow during the storm event is elevated by 2.5-, 7.5-, 5.0- (reference), 10-, and 12.5- fold for approximately 3 days (Figure S1).

- Surface radiation: The solar irradiance is varied between $80 \%$ and $120 \%$ of the reference magnitude with $10 \%$ intervals to address possible changes in surface radiation at the bay due to cloud cover change and air pollution (Figure S2).

- Water temperature: The bay water temperature is assumed to be $21,23,25,27$, and $29^{\circ} \mathrm{C}$, with $25^{\circ} \mathrm{C}$ being the reference (Figure S3).

- Water exchange: The rate of water exchange between the southern bay and the central bay (leading to open ocean) is increased and decreased by 10 and $20 \%$ from the reference rate (Figure S4).

- River runoff: The rate of river runoff is changed between 80 and $120 \%$ of the reference rate with $10 \%$ intervals (Figure S5).

\footnotetext{
${ }^{5}$ Except for the first set of experiments, the absolute magnitude and period of the storm perturbation are kept the same as the reference experiment for the present-day condition.
} 
- Biological metabolism: The power of the Michaelis-Menten kinetics $\left(c_{\mathrm{MM}}\right)$ used for the biotic reservoirs consistently (Table 1) is varied from 2.0 to 4.0 with an interval of 0.5 . In the reference case, the third power is used for all the biotic assimilation and grazing (Figure S6).

\subsection{Trophic State Estimation}

The trophic states are calculated using a N-based method (Kemp et al. 1997), in which the net ecosystem production (NEP) is characterized as an imbalance between DIN and total organic nitrogen (TON). In our study, NEP is defined as the magnitude of the net $\mathrm{N}$ transfer from the inorganic $\mathrm{N}$ pool (consisting of ammonium and nitrate reservoirs) to the organic $\mathrm{N}$ pool (comprising DON, PON, and all pelagic and benthic biotic reservoirs). Figure 4 shows several ways to estimate the NEP at steady state. If the net $\mathrm{N}$ transfer from the inorganic $\mathrm{N}$ pool to the organic $\mathrm{N}$ pool is positive (or the total fluxes are larger than the total respiration), the NEP is positive and the ecosystem is characterized as being autotrophic. Otherwise, the ecosystem is heterotrophic. It should be noted that the trophic state in our approach refers to all the $\mathrm{N}$ in the pelagic and benthic system as well as the sediments that are responsible for short-term nutrient regeneration and PON resuspension because the model does not take long-term processes in the sediments into account.

\section{Results and Discussion}

\subsection{Steady States Under Future Climate}

Each climate scenario has a varied impact on the ecosystem response (Fig. 3). In the following, we discuss the new steady states under the future climate scenarios and compare them with sensitivity results with only one climate parameter varied from present-day values (Figures S2 through S6). Such comparisons can be justified by a relatively strong linearity of the different effects-i.e., the sum of the responses to individual changes is relatively close to the response of all forcings (Table 3$)^{6}$

Overall, our results suggest that the hydrological change has a larger impact on the steady state than the change in temperature (Fig. 3). This can be mostly explained by changes in the riverine input (Figure S5), which is assumed to decrease by $10 \%$ under the drier climate (scenarios I and II) and increase by $10 \%$ under the wetter climate (scenarios I' and II'). The ecosystem as a whole slightly loses $\mathrm{N}$ under the drier climate; on the contrary, the ecosystem significantly gains $\mathrm{N}$ under the wetter climate (Fig. 3j). The same applies to the total pelagic $\mathrm{N}$ (Fig. 3k) and the total benthic $\mathrm{N}$ (Fig. 31). The relative fraction of the benthic $\mathrm{N}$ out of the total $\mathrm{N}(29.8 \%$ under the present-day condition) decreases slightly under the drier climate (28.9 and $29.5 \%$ under scenarios I and II,

\footnotetext{
${ }^{6}$ It is generally shown in Table 3 that the directions of changes in reservoir sizes under the future climate scenarios (Fig. 3) can be inferred by linear syntheses of directions of reservoir responses to corresponding individual parameter changes (Figures S2 through S6). However, it is not always so, which is most evident in the results for surface radiation and water temperature (Figures S2 and S3). In particular, the pelagic phytoplankton reservoir exhibits a strong nonlinear response to the cooling (Figure S3e). In the results with respect to water exchange and river runoff, nonlinearity is weaker (Figures S4 and S5) but does appear when these parameters are varied across larger ranges (e.g., up to $\pm 60 \%$ changes) (results not shown). The nonlinearities discussed here stem from the nonlinear formula used to describe the radiation and temperature control of biological metabolism (Table 1).
} 

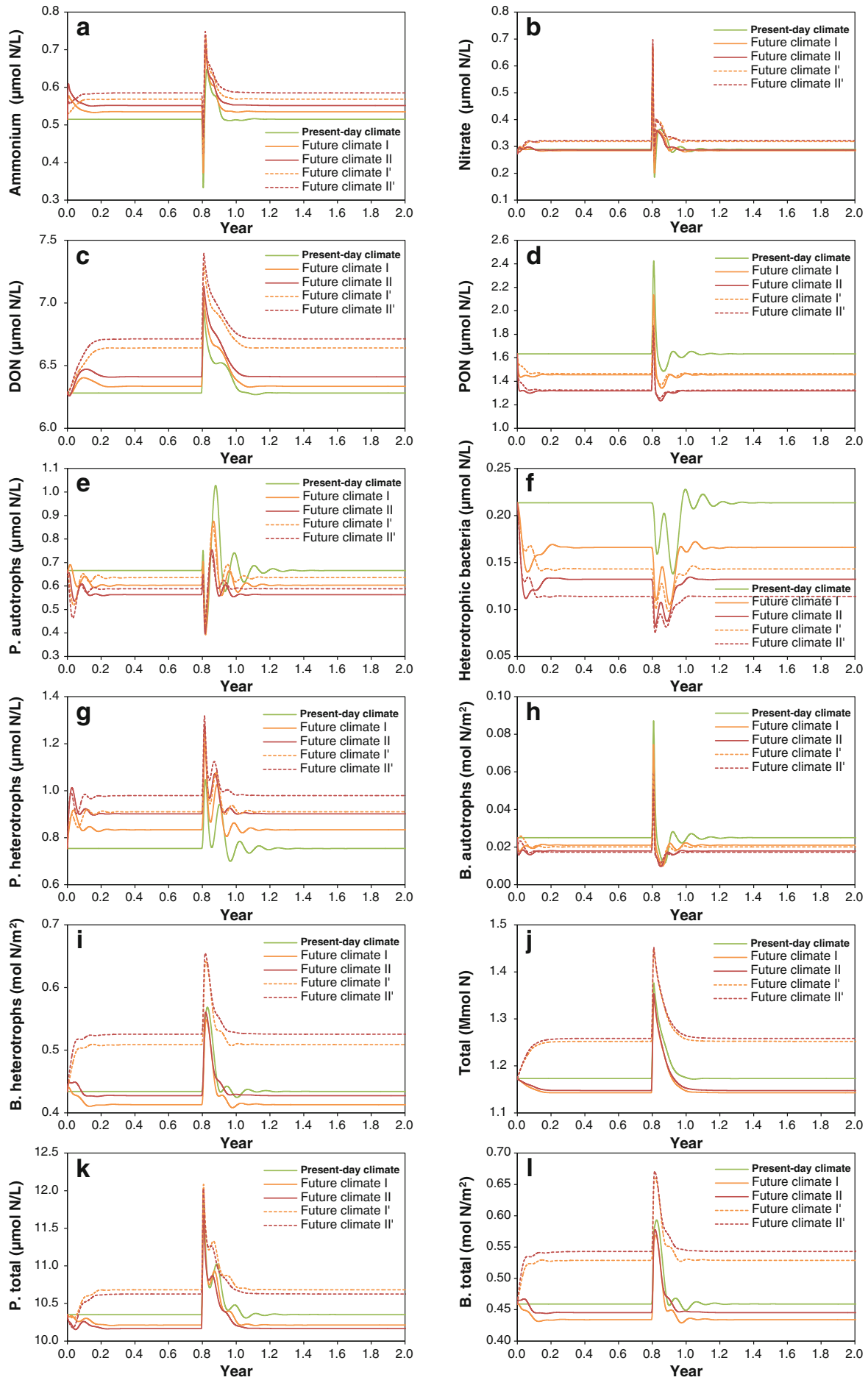
4 Fig. 3 Responses of the ecosystem to storm perturbations under illustrative present-day and future climate scenarios. The setup used for the run under the present-day climate is consistent with that used in (Tanaka and Mackenzie 2005). Details of the four future climate scenarios are summarized in Table 2 and discussed in the text. All the runs using the future climate scenarios start from the same present-day condition but under different climate scenarios, resulting in phases of initial adjustments. After the initial adjustments are complete (in year 0.8), storm perturbations are added in all the runs. Absolute magnitudes and durations of storm events are kept the same throughout the five runs

respectively) and increases under the wetter climate (32.1 and $32.8 \%$ under scenarios I' and II', respectively).

Interestingly, directions of changes in reservoir sizes are consistent under all the future scenarios [except for benthic heterotrophs (Fig. 3i)]. These results may point to a shift in ecosystem species composition in the future-however, such a statement would need to be supported by a more detailed modeling study because our model represents ecosystem species only in a simplified way. Below we discuss a few selected aspects of the results.

- The DON concentration becomes higher in all the four future scenarios. The sensitivity results indicate that the enhanced DON concentration is due to the warming, and the reduced mixing assumed in all the scenarios. The increase in the DON concentration under the warming is a result of feedbacks among biotic reservoirs, the respiration rates of which are temperature-dependent. In our model, temperature changes influence only biotic fluxes (Table 1). The higher DON concentration is accompanied by the lower concentration of heterotrophic bacteria, which is the only biota that grazes upon DON in our model. The enhanced DON level with a reduced mixing is due to the fact that the DON concentration outside the southern basin (i.e., central basin) is lower than that in the southern basin [Table 1 of (Tanaka and Mackenzie 2005)].

- The abundance of heterotrophic bacteria is projected to decrease (by up to about $50 \%$ ) under all the future climate scenarios. This is predominantly due to the warming (Figure S3), followed by the change in river runoff (Figure S5). Higher temperature leads to a decrease in heterotrophic bacteria, which is a combined effect of the temperature-dependent respiration fluxes of all the biotic reservoirs. The decreased bacteria population is accompanied by the higher concentration of pelagic heterotrophs, which suppresses the bacteria population. An elevated rate of river runoff, which contains higher concentrations of nitrate, DON, and PON than in the bay water [Table 1 of (Tanaka and Mackenzie 2005)], induces the increases in all the reservoirs except for the bacteria and the benthic autotrophs. The rate of river runoff is assumed to decline in the drier climate scenarios, which leads to an increase in the bacteria reservoir size. But such an effect is not strong enough to compensate the suppression of the bacteria reservoir caused by the warming.

\subsection{Trophic States Under Future Climate}

Changes in the ecosystem trophic states and $\mathrm{N}$ budgets under the climate scenarios are shown in Fig. 4. The NEP of the present-day ecosystem is positive, indicating autotrophy. Under the drier scenarios (I and II), the level of autotrophy significantly declines (by 13 and $16 \%$, respectively). On the contrary, under the wetter scenarios (I' and II'), the autotrophic level slightly rises (by 3.7 and $0.81 \%$, respectively).

To understand what controls the NEP, we first look into the gross DIN:TON loading ratio (DIN/TON thereafter), which is shown to have a positive relationship with the NEP in several US estuaries (Boynton and Kemp 2008). However, our range of DIN/TON is small 


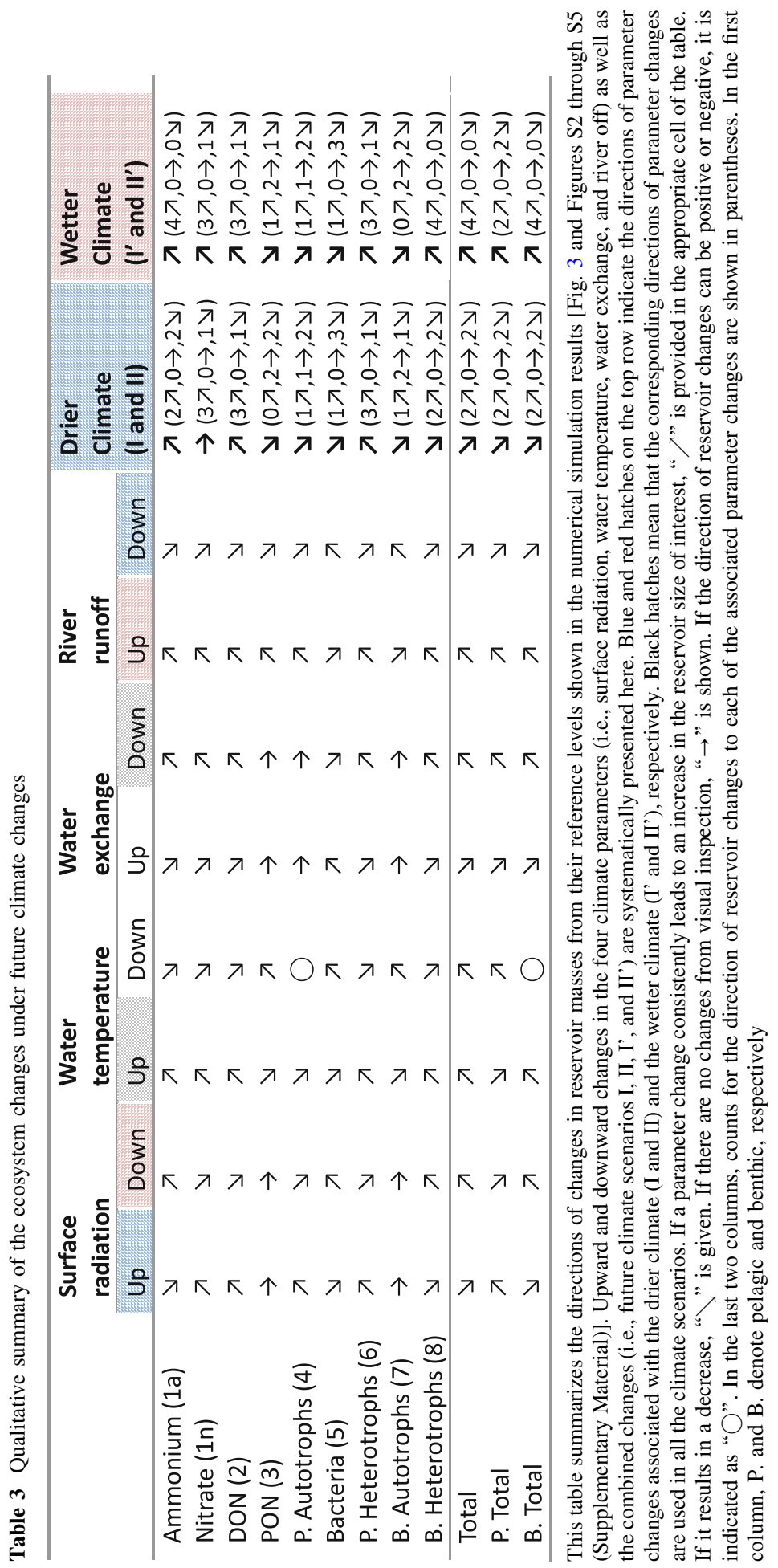




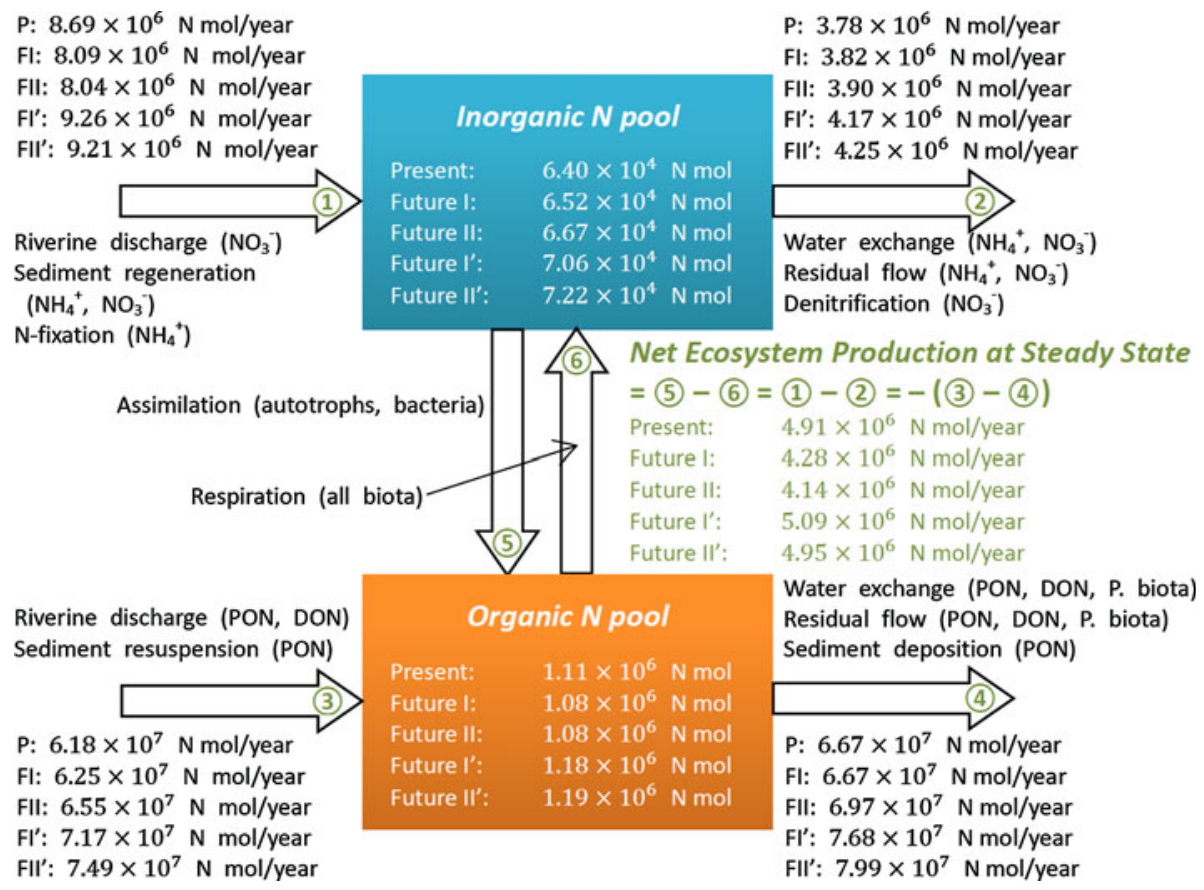

Fig. $4 \mathrm{~N}$ budgets and trophic states of the bay ecosystem under illustrative present-day and future climate. Estimates of the aggregated input and output are based on the model ecosystems equilibrated under different climate states (Table 2 and Fig. 3). The inorganic $\mathrm{N}$ pool is the sum of the ammonium and nitrate reservoirs; the organic $\mathrm{N}$ pool contains all the other biotic and abiotic reservoirs (Fig. 2). The magnitudes of the numbered input and output are sums of the sizes of the associated fluxes listed in the figure

(from 12.3 to $14.1 \%$ ), and a consistent relationship is not identified in our results (Fig. 5), indicating that factors that are not captured by the DIN/TON are important in determining the NEP in our model.

Our results reveal that it is primarily the temperature that determines the NEP (Fig. 5). A change in each climate parameter causes a shift in the estimates of the NEP and DIN/ TON along a unique direction. Within the parameter ranges we considered, the water temperature has the largest influence on the NEP, followed by the river runoff. In fact, these two parameters largely explain the estimates of the NEP and DIN/TON under the future climate scenarios. While the NEP is more or less linearly related to the river runoff rate, the temperature-dependence of the NEP is nonlinear as a result of the exponential formula for the temperature sensitivity of the biological metabolism (Table 1). The NEP becomes increasingly larger with lower temperature.

The impact of the surface radiation, which negatively influences the NEP, may appear counter-intuitive at first but is a result of feedbacks in the nutrient cycle. Figure S2 shows that under enhanced surface radiation, the pelagic autotroph biomass adjusts to an elevated level and is accompanied by an increase in the pelagic heterotroph biomass. The benthic system responds differently: Benthic autotrophs respond to the enhanced radiation in the beginning negatively due to the shading effect of the pelagic phytoplankton bloom but return back to their initial level; benthic heterotrophs, however, find a new different equilibrium. These complex feedbacks are responsible for the change in NEP estimates 


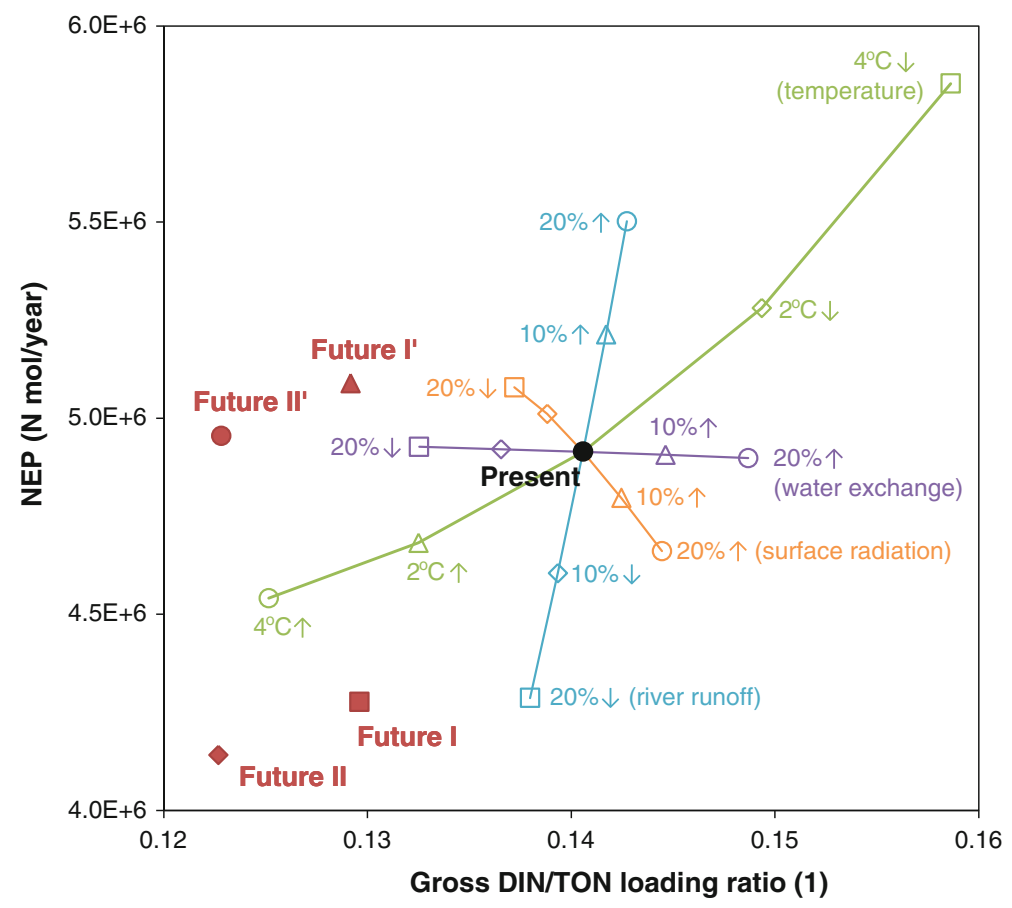

Fig. 5 NEP and gross DIN/TON input of the southern Kaneohe Bay under various climate conditions. Estimates of NEP and gross DIN/TON input of the southern Kaneohe Bay under the present-day and four future climates (Table 2 and Fig. 3) are compared with those under the sensitivity cases in which climate parameters are varied individually from the present-day values (Figures S2 through S6). The experimental setups and the trophic state estimation method are described in Sects. 2.3 and 2.4, respectively. The plots and their explanations are coded in corresponding color. Symbols up arrow and down arrow indicate "increase" and "decrease", respectively

under different solar irradiance, although this result is contingent on various assumptions in our model.

One assumption that may significantly change our current results is the stream water composition that is kept constant in the future and also invariant between the baseline and storm conditions, although observations show otherwise (Hoover and Mackenzie 2009; Wong 2013). This assumption may have a sizeable impact on the NEP estimates because the river runoff is an important factor in determining the NEP (Fig. 5).

\subsection{Ecosystem Stability Under Future Climate}

In this section, we discuss how the changes in future climate influence the ecosystem stability, which is in our definition the timescale of the ecosystem to return back to its steady state after being perturbed by an external forcing. Under the future climate, most of the reservoirs show faster recoveries from storm perturbations than under the present-day climate (Figs. 3a through 3i), although the overall period of recovery in terms of the total $\mathrm{N}$ remains virtually unchanged (Fig. 3j). In other words, some reservoirs undergo oscillations along the perturbation decay, but these oscillations are largely canceled out at the ecosystem level. 
Our results indicate that the ecosystem stability is influenced more by changes in temperature than in hydrology. The lower the water temperature is, the less stable the ecosystem is (Figure S3). The temperature influences the ecosystem stability through the temperature sensitivity of biological metabolism, in which magnitudes of respiration fluxes become smaller under lower temperature. The hydrological impact on the ecosystem stability is not very evident because the ecosystem exhibits a higher stability under lower surface radiation (Figure S2) and under reduced river runoff (Figure S5). These effects work in opposing directions when the results under the climate scenarios I and I' (or II and II') are compared.

The foregoing results are not very dependent on the particular magnitude of perturbations used in our experiments (Figure S1). The magnitudes of the changes in the reservoir masses in response to a perturbation are, at first approximation, linearly related to the perturbation magnitude. The phase of the fluctuations in the reservoir masses is nearly consistent across different storm sizes. In other words, key features of the model response remain the same under different storm magnitudes.

Note, however, that the preceding results are contingent on the formulation of biological metabolism (Table 1). The stability of our modeled ecosystem strongly depends on the assumed power coefficient of the Michaelis-Menten kinetic function as shown by a mathematical eigenanalysis ${ }^{7}$ [Figs. 3.18 and 3.19 of (Tanaka 2002); (Tanaka and Mackenzie 2005)] as well as numerical simulations (Figure S6).

\section{Concluding Remarks}

We explored annual-mean impacts on the Kaneohe Bay ecosystem under conceivable future climate changes toward the end of this century. Our future climate scenarios include a set of cases addressing different levels of warming [i.e., moderate warming (scenarios I and I') and enhanced warming (scenarios II and II')] as well as hydrologically contrasting cases [i.e., drier conditions (scenarios I and II) and wetter conditions (scenarios I' and II')]. By using an $\mathrm{N}$ cycle biogeochemical model of the pelagic and benthic ecosystem of the Kaneohe Bay, we investigated changes in the ecosystem steady state, trophic state, and stability under such climate scenarios.

Given assumptions in our model and future climate scenarios, our results indicate several fundamental features and possible future changes in the ecosystem.

- Hydrological changes are more important in determining the ecosystem structure than temperature changes. In the drier future, the ecosystem as a whole slightly loses N. The $\mathrm{N}$ distribution in the ecosystem moves marginally toward the pelagic system. On the contrary, in the wetter future, the entire ecosystem gains $\mathrm{N}$ significantly and the $\mathrm{N}$ balance shifts toward the benthic system. The directions of changes in the ecosystem components are mostly consistent under all the scenarios. Among them, the DON concentration increases and the heterotrophic bacteria are suppressed.

\footnotetext{
7 The eigenproperty of the model, which is derived both analytically and numerically (Tanaka 2002; Tanaka and Mackenzie 2005), can then be more utilized in future studies. Eigenproperties of ecosystem models are widely used in the field of mathematical ecology [e.g., (May 1973)] although their limitations in revealing ecosystem stabilities are debated (Neubert and Caswell 1997; Hastings 2004; Verdy and Caswell 2008). To our knowledge, only several empirical modeling studies obtain eigenproperties (Carpenter et al. 1992; Cottingham and Carpenter 1994; Laws 1997; Tanaka and Mackenzie 2005; Montoya et al. 2009).
} 
- Temperature changes influence NEP more strongly than the hydrological changes do, although NEP is tightly coupled with both hydrological and climatic conditions. The current autotrophic state continues in the future-however, the ecosystem becomes less autotrophic under drier climate but slightly more autotrophic under wetter climate. In terms of single climate parameters, the temperature has the largest impact on NEP, followed by the river runoff. The larger the warming is, the less autotrophic the ecosystem becomes. A larger river runoff makes the ecosystem more autotrophic.

- Temperature changes affect the model response to a storm perturbation more strongly than hydrological changes. Oscillating behaviors exhibited in individual reservoirs decay faster under hotter climate, although the overall ecosystem stability is not significantly affected by temperature changes.

Disturbing the $\mathrm{N}$ cycle may alter the ecosystem structure, trophic state, and stability of the ecosystem because $\mathrm{N}$ is the limiting nutrient of the bay ecosystem. These findings are germane for tropical and subtropical ecosystems in similar settings.

While these insights obtained from our current modeling approach are useful, there are limitations. First, the model KECOM does not account for the linkages between the N cycle and the cycles of other elements such as C and P [cf. (Ver et al. 1999; Gruber and Galloway 2008; Mackenzie et al. 2011)]—in other words, N cycle processes are assumed to be insensitive to any change in other biogeochemical cycling processes. Second, the pelagic and benthic systems are combined and treated as single domains within which $\mathrm{N}$ cycle processes are assumed to take place homogeneously. Third, our model setup addresses only annual-mean changes in the ecosystem. Fourth, long-term processes in the sediments [i.e., early diagenesis (Berner 1980)] are not described in the model. Fifth, our assumption on the strength of the assimilation and grazing kinetics of the biota [i.e., the power constants of the Michaelis-Menten kinetics (Tanaka and Mackenzie 2005)] strongly influences the model response to a storm perturbation.

Thus, future studies would benefit by addressing how the interconnected cycles of $\mathrm{C}, \mathrm{N}$, and $\mathrm{P}$ of the bay ecosystem feedback on each other as a result of the global and regional climate change. In addition, adding an oxygen cycle to the model would allow an explicit evaluation of the oxygen state of the bay ecosystem. We think that the time is ripe for an implementation of other element cycles to the model also because multiple-year data for continuous monitoring of water quality parameters in the Kaneohe Bay are now available [i.e., CRIMP and CRIMP2 projects (Drupp et al. 2011)] and essential for such coupled model tuning. However, actual implementations of these developments need to be carefully assessed because building a more complex model does not necessarily promise a better scientific understanding [e.g., (Anderson 2005)].

The climatic influence of the ecosystem structure, trophic status, and stability would have implications for the overall future health of the bay ecosystem as well as its esthetic and recreational value. Further modeling studies on the bay ecosystem are therefore not only useful for the advancement of scientific understanding of the bay ecosystem but also possibly preservation of these coastal ecosystems.

Acknowledgments We thank Eric De Carlo for coordinating the Special Issue honoring the career of Fred Mackenzie. We are grateful for Eric De Carlo, Fred Mackenzie, and two anonymous reviewers for comments and feedbacks during the course of this study. K. Tanaka is thankful for Jan Sedlacek for his technical help for retrieving and plotting the CMIP5 data and for Oliver Stebler for his tips to improve the visual presentation of the model diagram. The photograph used as the background of Fig. 2 is credited for Jennifer O. Reynolds. CRIMP and CRIMP2 projects as well as the NOAA/PMEL Carbon Dioxide Program are acknowledged for the climate data collected at Kaneohe Bay. K. Tanaka is supported by a Marie Curie IntraEuropean Fellowship within the 7th European Community Framework Programme (Proposal N ${ }^{\circ} 255568$ 
under FP7-PEOPLE-2009-IEF). N. Gruber acknowledges financial support by ETH Zurich. The first author designed and constructed the model KECOM as a part of his master thesis under the guidance of Fred Mackenzie (Tanaka 2002). He is pursuing his research career in the field of Earth system science (Mackenzie 2011) and his Marie Curie Fellowship project aims to elucidate the uncertainty and stability property of a coupled C-N-P biogeochemical cycle model (Ver et al. 1999; Mackenzie et al. 2011; Joos et al. 2013). By taking the opportunity to honor Fred's career, the first author revisits KECOM and addresses questions related to climate change, which he currently works on [e.g., (Tanaka et al. 2007, 2009, 2012, 2013)].

\section{References}

Anderson TR (2005) Plankton functional type modeling: running before we can walk? J Plankton Res 27:1073-1081

Archer D, Eby M, Brovkin V, Ridgwell A, Cao L, Mikolajewicz U, Caldeira K, Matsumoto K, Munhoven G, Montenegro A, Tokos K (2009) Atmospheric lifetime of fossil fuel carbon dioxide. Annu Rev Earth Planet Sci 37:117-134

Berner RA (1980) Early diagenesis : A theoretical approach. Princeton University Press, Princeton

Boynton WR, Kemp WM (2008) Chapter 18-estuaries. In: Nitrogen in the marine environment (2nd edition). Academic Press, San Diego, pp 809-866

Braganza K, Karoly DJ, Arblaster JM (2004) Diurnal temperature range as an index of global climate change during the twentieth century. Geophys Res Lett 31:L13217

Buddemeier RW, Kleypas JA, Aronson RB (2004) Global reefs and global climate change: potential contributions to climate change to stresses on coral reef ecosystems. Pew center on global climate change

Caperon J (1975) A trophic level ecosystem model analysis of the plankton community in a shallow-water subtropical estuarine embayment. In: Cronin LE (ed) Estuarine research: Chemistry, biology, and the estuarine system. Academic Press, Waltham, pp 691-709

Carpenter SR, Kraft CE, Wright R, He X, Soranno PA, Hodgson JR (1992) Resilience and resistance of a lake phosphorus cycle before and after food web manipulation. Am Nat 140:781-798

Carpenter KE, Abrar M, Aeby G, Aronson RB, Banks S, Bruckner A, Chiriboga A, Cortés J, Delbeek JC, DeVantier L, Edgar GJ, Edwards AJ, Fenner D, Guzmán HM, Hoeksema BW, Hodgson G, Johan O, Licuanan WY, Livingstone SR, Lovell ER, Moore JA, Obura DO, Ochavillo D, Polidoro BA, Precht WF, Quibilan MC, Reboton C, Richards ZT, Rogers AD, Sanciangco J, Sheppard A, Sheppard C, Smith J, Stuart S, Turak E, Veron JEN, Wallace C, Weil E, Wood E (2008) One-third of reef-building corals face elevated extinction risk from climate change and local impacts. Science 321:560-563

Chu P-S, Chen YR, Schroeder TA (2010) Changes in precipitation extremes in the Hawaiian islands in a warming climate. J Clim 23:4881-4900

Cottingham KL, Carpenter SR (1994) Predictive indices of ecosystem resilience in models of north temperate lakes. Ecology 75:2127-2138

Cox EF, Ribes M, Kinzie III RA (2006) Temporal and spatial scaling of planktonic responses to nutrient inputs into a subtropical embayment. Mar Ecol Prog Ser 324:19-35

De Carlo EH, Hoover DJ, Young CW, Hoover RS, Mackenzie FT (2007) Impact of storm runoff from tropical watersheds on coastal water quality and productivity. Appl Geochem 22:1777-1797

Doney SC (2010) The growing human footprint on coastal and open-ocean biogeochemistry. Science 328:1512-1516

Drupp P, De Carlo E, Mackenzie F, Bienfang P, Sabine C (2011) Nutrient inputs, phytoplankton response, and $\mathrm{CO}_{2}$ variations in a semi-enclosed subtropical embayment, Kaneohe bay, Hawaii. Aquat Geochem 17:473-498

Dugdale RC (1967) Nutrient limitation in the sea: dynamics, identification, and significance. Limnol Oceanogr 12:685-695

Fagan KE, Mackenzie FT (2007) Air-sea $\mathrm{CO}_{2}$ exchange in a subtropical estuarine-coral reef system, Kaneohe bay, Oahu, Hawaii. Mar Chem 106:174-191

Fennel W (1995) A model of the yearly cycle of nutrients and plankton in the Baltic Sea. J Mar Syst 6:313-329

Galloway JN, Dentener FJ, Capone DG, Boyer EW, Howarth RW, Seitzinger SP, Asner GP, Cleveland CC, Green PA, Holland EA, Karl DM, Michaels AF, Porter JH, Townsend AR, Vöosmarty CJ (2004) Nitrogen cycles: past, present, and future. Biogeochemistry 70:153-226 
Garza JA, Chu P-S, Norton CW, Schroeder TA (2012) Changes of the prevailing trade winds over the islands of Hawaii and the north pacific. J Geophys Res 117:D11109

Giambelluca TW, Diaz HF, Luke MSA (2008) Secular temperature changes in Hawaii. Geophys Res Lett 35:L12702

Gross T, Ebenhöh W, Feudel U (2004) Enrichment and food chain stability: the impact of different forms of predator-prey interaction. J Theor Biol 227:349-358

Gruber N (2008) Chapter 1-the marine nitrogen cycle: overview and challenges. In: Nitrogen in the marine environment (2nd edition). Academic Press, San Diego, pp 1-50

Gruber N (2011) Warming up, turning sour, losing breath: ocean biogeochemistry under global change. Phil Trans R Soc A 369:1980-1996

Gruber N, Galloway JN (2008) An earth-system perspective of the global nitrogen cycle. Nature 451:293-296

Guidry MW, Dumas D, Mackenzie FT, De Carlo EH (2012) Land - coastal ocean interactions in the tropics and subtropics: Hawai'i as an example. Honolulu, Hawaii

Hastings A (2004) Transients: the key to long-term ecological understanding? Trends Ecol Evol 19:39-45

Hoover D (2002) Fluvial nitrogen and phosphorus in hawaii: Storm runoff, land use, and impacts on coastal waters. University of Hawaii at Manoa, Honolulu, Hawaii, US, Ph. D. dissertation

Hoover DJ, Mackenzie FT (2009) Fluvial fluxes of water, suspended particulate matter, and nutrients and potential impacts on tropical coastal water biogeochemistry: oahu, Hawaii. Aquat Geochem 15:547-570

Jokiel PL, Brown EK (2004) Global warming, regional trends and inshore environmental conditions influence coral bleaching in Hawaii. Global Change Biol 10:1627-1641

Jokiel PL, Hunter CL, Taguchi S, Watarai L (1993) Ecological impact of a fresh-water "reef kill" in Kaneohe bay, Oahu, Hawaii. Coral Reefs 12:177-184

Joos F, Roth R, Fuglestvedt JS, Peters GP, Enting IG, von Bloh W, Brovkin V, Burke EJ, Eby M, Edwards NR, Friedrich T, Frölicher TL, Halloran PR, Holden PB, Jones C, Kleinen T, Mackenzie FT, Matsumoto K, Meinshausen M, Plattner G-K, Reisinger A, Segschneider J, Shaffer G, Steinacher M, Strassmann K, Tanaka K, Timmermann A, Weaver AJ (2013) Carbon dioxide and climate impulse response functions for the computation of greenhouse gas metrics: a multi-model analysis. Atmos Chem Phys 13:2793-2825

Kemp W, Smith E, Marvin-DiPasquale M, Boynton W (1997) Organic carbon balance and net ecosystem metabolism in Chesapeake bay. Mar Ecol Prog Ser 150:229-248

Knutti R (2010) The end of model democracy? Clim Change 102:395-404

Laws EA (1997) Mathematical methods for oceanographers: An introduction. John Wiley \& Sons Inc., New York

Laws EA, Allen CB (1996) Water quality in a subtropical embayment more than a decade after division of sewage discharges. Pac Sci 50:194-210

Laws EA, Falkowski PG, Smith WO, Ducklow H, McCarthy JJ (2000) Temperature effects on export production in the open ocean. Global Biogeochem Cycles 14:1231-1246

Lowe RJ, Falter JL, Monismith SG, Atkinson MJ (2009) A numerical study of circulation in a coastal reeflagoon system. J Geophys Res 114:C06022

Mackenzie FT (2011) Our changing planet: An introduction to earth system science and global environmental change, 4th edn. Prentice Hall, Boston

Mackenzie FT, Lerman A (2006) Carbon in the geobiosphere: - earth's outer shell. Springer, Dordrecht

Mackenzie FT, Lerman A, Ver LMB (1998) Role of the continental margin in the global carbon balance during the past three centuries. Geology 26:423-426

Mackenzie FT, De Carlo EH, Lerman A (2011) Coupled c, n, p, and o biogeochemical cycling at the landocean interface. In: Wolanski E, McLusky DS (eds) Treatise on estuarine and coastal science, vol 5. Academic Press, Waltham, pp 317-342

Massaro RS, Carlo E, Drupp P, Mackenzie F, Jones S, Shamberger K, Sabine C, Feely R (2012) Multiple factors driving variability of $\mathrm{CO}_{2}$ exchange between the ocean and atmosphere in a tropical coral reef environment. Aquat Geochem 18:357-386

May RM (1973) Stability and complexity in model ecosystems. Princeton University Press, Princeton, New Jersey, US, Princeton landmarks in biology

Meehl GA, Tebaldi C, Nychka D (2004) Changes in frost days in simulations of twenty first century climate. Clim Dyn 23:495-511

Montoya JM, Woodward G, Emmerson MC, Solé RV (2009) Press perturbations and indirect effects in real food webs. Ecology 90:2426-2433

Moss RH, Edmonds JA, Hibbard KA, Manning MR, Rose SK, van Vuuren DP, Carter TR, Emori S, Kainuma M, Kram T, Meehl GA, Mitchell JFB, Nakicenovic N, Riahi K, Smith SJ, Stouffer RJ, 
Thomson AM, Weyant JP, Wilbanks TJ (2010) The next generation of scenarios for climate change research and assessment. Nature 463:747-756

Neubert MG, Caswell H (1997) Alternatives to resilience for measuring the responses of ecological systems to perturbations. Ecology 78:653-665

Norton CW, Chu P-S, Schroeder TA (2011) Projecting changes in future heavy rainfall events for Oahu, Hawaii: a statistical downscaling approach. J Geophys Res 116:D17110

Ohmura A (2009) Observed decadal variations in surface solar radiation and their causes. J Geophys Res 114:D00D05

Ostrander C, McManus M, DeCarlo E, Mackenzie F (2008) Temporal and spatial variability of freshwater plumes in a semi enclosed estuarine-bay system. Estuar Coasts 31:192-203

Pace ML, Glasser JE, Pomeroy LR (1984) A simulation analysis of continental shelf food webs. Mar Biol $82: 47-63$

Rabouille C, Mackenzie FT, Ver LM (2001) Influence of the human perturbation on carbon, nitrogen, and oxygen biogeochemical cycles in the global coastal ocean. Geochim Cosmochim Acta 65:3615-3641

Rees AP (2012) Pressures on the marine environment and the changing climate of ocean biogeochemistry. Phil Trans R Soc A 370:5613-5635

Regnier P, Friedlingstein P, Ciais P, Mackenzie FT, Gruber N, Janssens I, Laruelle GG, Lauerwald R, Luyssaert S, Andersson AJ, Arndt S, Arnosti C, Borges AV, Dale AW, Gallego-Sala A, Goddéris Y, Hartmann J, Heinze C, Ilyina T, Joos F, LaRowe DE, Leifeld J, Meysman FJR, Munhoven G, Goossens N, Raymond PA, Spahni R, Suntharalingam P, Thullner M (2013) Global carbon budget and its anthropogenic perturbation in the land-ocean aquatic continuum. Nature geoscience 6:597-607

Ringuet S, Mackenzie F (2005) Controls on nutrient and phytoplankton dynamics during normal flow and storm runoff conditions, southern Kaneohe bay, Hawaii. Estuar Coasts 28:327-337

Safeeq M, Fares A (2012) Hydrologic response of a Hawaiian watershed to future climate change scenarios. Hydrol Processes 26:2745-2764

Scheinberg RD, Landry MR, Calbet A (2005) Grazing of two common appendicularians on the natural prey assemblage of a tropical coastal ecosystem. Mar Ecol Prog Ser 294:201-212

Seneviratne SI, Nicholls N, Easterling D, Goodess CM, Kanae S, Kossin J, Luo Y, Marengo J, McInnes K, Rahimi M, Reichstein M, Sorteberg A, Vera C, Zhang X (2012) Changes in climate extremes and their impacts on the natural physical environment. In: Field CB, Barros V, Stocker TF et al (eds) A special report of working groups $\mathrm{i}$ and ii of the intergovernmental panel on climate change (ipcc). Cambridge University Press, Cambridge, pp 109-230

Shamberger KEF, Feely RA, Sabine CL, Atkinson MJ, DeCarlo EH, Mackenzie FT, Drupp PS, Butterfield DA (2011) Calcification and organic production on a Hawaiian coral reef. Mar Chem 127:64-75

Skeie RB, Berntsen TK, Myhre G, Tanaka K, Kvalevåg MM, Hoyle CR (2011) Anthropogenic radiative forcing time series from pre-industrial times until 2010. Atmos Chem Phys 11:11827-11857

Smith SV, Hollibaugh JT (1993) Coastal metabolism and the oceanic organic carbon balance. Rev Geophys 31:75-89

Smith SV, Kimmerer WJ, Laws EA, Brock RE, Walsh TW (1981) Kaneohe bay sewage diversion experiment: perspectives on ecosystem responses to nutritional perturbation. Pac Sci 35:279-395

Smith J, Smith C, Hunter C (2001) An experimental analysis of the effects of herbivory and nutrient enrichment on benthic community dynamics on a Hawaiian reef. Coral Reefs 19:332-342

Smith JE, Hunter CL, Smith CM (2002) Distribution and reproductive characteristics of non indigenous and invasive marine algae in the Hawaiian islands. Pac Sci 56:299-315

Solomon S, Daniel JS, Sanford TJ, Murphy DM, Plattner G-K, Knutti R, Friedlingstein P (2010) Persistence of climate changes due to a range of greenhouse gases. Proc Natl Acad Sci 107:18354-18359

Solomon S, Daniel JS, Neely RR, Vernier J-P, Dutton EG, Thomason LW (2011) The persistently variable "background" stratospheric aerosol layer and global climate change. Science 333:866-870

Stone DA, Weaver AJ (2002) Daily maximum and minimum temperature trends in a climate model. Geophys Res Lett 29:1356

Summerhayes CP (1995) Upwelling in the ocean: modern processes and ancient records: report of the Dahlem workshop on upwelling in the ocean, modern processes and ancient records, Berlin 1994, September 25-30. Environmental sciences research report; es 18. John Wiley, Chichester, England; New York

Tanaka K (2002) Statistical and stability analysis of ecosystem dynamics in southern Kaneohe bay. M.S. thesis, University of Hawaii at Manoa, Honolulu, Hawaii, US. http://hdl.handle.net/10125/6964

Tanaka K, Mackenzie FT (2005) Ecosystem behavior of southern Kaneohe bay, Hawaii: a statistical and modeling approach. Ecol Model 188:296-326

Tanaka K, Raddatz T (2011) Correlation between climate sensitivity and aerosol forcing and its implication for the "climate trap". Clim Change 109:815-825 
Tanaka K, Kriegler E, Bruckner T, Hooss G, Knorr W, Raddatz T (2007) Aggregated Carbon Cycle, Atmospheric Chemistry, and Climate model (ACC2) - description of the forward and inverse modes. Reports on earth system science, vol 40. Max Planck Institute for Meteorology, Hamburg. http://hdl. handle.net/11858/00-001M-0000-0011-FB8B-5

Tanaka K, Raddatz T, O’Neill BC, Reick CH (2009) Insufficient forcing uncertainty underestimates the risk of high climate sensitivity. Geophys Res Lett 36:L16709

Tanaka K, Berntsen T, Fuglestvedt JS, Rypdal K (2012) Climate effects of emission standards: the case for gasoline and diesel cars. Environ Sci Technol 46:5205-5213

Tanaka K, Johansson DJA, O’Neill BC, Fuglestvedt JS (2013) Emission metrics under the $2{ }^{\circ} \mathrm{C}$ climate stabilization target. Clim Change 117:933-941

Taylor KE, Stouffer RJ, Meehl GA (2011) An overview of cmip5 and the experiment design. Bull Am Meteorol Soc 93:485-498

Timm O, Diaz HF (2009) Synoptic-statistical approach to regional downscaling of ipcc twenty-first-century climate projections: seasonal rainfall over the Hawaiian islands. J Clim 22:4261-4280

US-Census-Bureau (2012) State and county quick facts. http://quickfacts.census.gov/qfd/index.html

Ver LMB, Mackenzie FT, Lerman A (1994) Modeling pre-industrial c-n-p-s biogeochemical cycling in the land-coastal margin system. Chemosphere 29:855-887

Ver LMB, Mackenzie FT, Lerman A (1999) Biogeochemical responses of the carbon cycle to natural and human perturbations: past, present, and future. Am J Sci 299:762-801

Verdy A, Caswell H (2008) Sensitivity analysis of reactive ecological dynamics. Bull Math Biol 70:1634-1659

White P, Kalff J, Rasmussen J, Gasol J (1991) The effect of temperature and algal biomass on bacterial production and specific growth rate in freshwater and marine habitats. Microb Ecol 21:99-118

Wild M (2009) Global dimming and brightening: a review. J Geophys Res 114:D00D16

Wong M (2013) Carbon system dynamics in streams discharging to kaneohe bay, hawaii. University of Hawaii at Manoa, Honolulu 